\title{
Effect of anticancer drugs on breast cancer cells sensitive and resistant to doxorubicin: expression of mRNAs of TGF- $\beta$ and its receptors
}

\author{
I. V. Chorna' ${ }^{1}$ O. V. Fedorenko², R. S. Stoika ${ }^{2}$ \\ ${ }^{1}$ Sumy State University, Ukraine \\ 2, Rimskogo-Korsakova Str., Sumy, Ukraine, 40007 \\ ${ }^{2}$ Institute of Cell Biology, NAS of Ukraine \\ 14/16, Drahomanov Str., Lviv, Ukraine, 79005 \\ stoika@cellbiol.lviv.ua
}

\begin{abstract}
Aim. Comparative study of the effect of chemotherapeutic drugs (doxorubicin, methotrexate and cisplatin) and $T G F-\beta$ on the human breast carcinoma MCF-7 cells, sensitive (wt) and resistant (DOX/R) to the doxorubicin action. Methods. Semi-quantitative reverse transcriptase-polymerase chain reaction (RT-PCR) was used for the estimation of expression of $m R N A$ s coding for the TGF- $\beta$ isoforms $\left(T G F-\beta_{1}\right.$ and TGF- $\left.\beta_{2}\right)$ and the TGF- $\beta$ type I and II receptors (TBRI and T $\beta R I I)$. Trypan blue exclusion method was used for measuring cell number and cell viability. Results. The MCF-7(DOX/R) cells were more refractory to the TGF $\beta_{1}$-dependent growth inhibition than the $M C F-7(w t)$ cells. The level of mRNAs coding for TGF- $\beta$ and its receptors was higher in the untreated MCF-7 (DOX/R) cells comparing to the MCF-7(wt) cells. The expression of mRNA coding for TBRII was decreased in both cell lines treated with doxorubicin, methotrexate and cisplatin, while the down-regulation of mRNA coding for TRRI was revealed only in the MCF-7(DOX/R) cells upon the treatment with doxorubicin and methotrexate. Conclusions. The differential effects of studied anticancer drugs and TGF- $\beta$ on the doxorubicin-sensitive and -resistant cells have been demonstrated. The elucidation of the molecular mechanisms of escape of the MCF-7 $(D O X / R)$ cells from the growth inhibition by TGF- $\beta$ requires further investigation.
\end{abstract}

Keywords: MCF-7, TGF- $\beta$, doxorubicin, methotrexate, cisplatin, resistance.

Introduction. Chemotherapy is a major tool in the treatment of breast cancer. However, the main problem hindering the success of chemotherapy is the development of acquired tumor drug resistance during the treatment. Although the most common chemotherapeutic drugs used for the breast cancer treatment cause DNA damage and induce apoptosis, they exert the cell killing effects through different molecular mechanisms. The biological effects displayed by doxorubicin that may be responsible for the inhibition of tumor cell growth involve the covalent DNA binding and DNA cross-linking, topoisomerase II inhibition, arrest of tumor cell cycle progression in $\mathrm{G} 2$ phase, induction of apoptosis

(C) Institute of Molecular Biology and Genetics, NAS of Ukraine, 2014 and free radicals formation $[1,2]$. The alkylating agent cisplatin binds to DNA bases causing intra- and interstrand cross-links and breaks in DNA strands, and thus, interfering with the DNA replication [3]. The antimetabolite methotrexate inhibits the enzyme dihydrofolate reductase preventing normal synthesis of the nucleoside triphosphates [4].

The tumor cells, resistant to a single chemotherapeutic agent, can also become cross-resistant to several other anti-cancer drugs due to the development of their multi-drug resistance. Such resistance was shown to be associated with numerous mechanisms: 1) decreased drug accumulation and/or altered intracellular distribution of drugs; 2) increased activity of the cell detoxification systems; 3 ) alterations in the cell cycle and signal 
transduction pathways; 4) increased repair of DNA damage and high anti-apoptotic potential of the tumor cells [5-7].

The multi-drug resistance in the MCF-7(DOX/R) cells was shown to be associated with various mechanisms including the over-expression of P-glycoprotein, glutathione S-transferase and glutathione peroxidase, the loss of estrogen responsiveness, the DNA hypomethylation (loss of cytosine methylation of the MDR1, GST $\pi$ and MGMT chemoresistance related genes) [6, $8]$, and the changes in the expression of several cell cycle regulators (decreased Ki-67, cyclin D1 and pRb and increased p21 expression) [9]. The elucidation of novel mechanisms of drug resistance and further development of the ways of overcoming such resistance or preventing its occurrence might increase the efficiency of treatment of cancer patients.

TGF- $\beta$ belongs to the most perspective molecular markers which have both prognostic and predictive significance in the breast cancer $[10,11]$. This cytokine is involved either in the regulation of cell proliferation, differentiation, apoptosis or in the intracellular and extracellular processes which contribute to the tumor progression (e.g. pro-tumorigenic effects on the vascular, immune and fibroblastic cells) [10]. However, TGF- $\beta$ may induce the entirely different cellular responses, depending on the cell type and the stimulation context, under both physiological and pathological conditions [12]. An alteration in the expression of the TGF- $\beta$ receptors and the post-receptor signal transduction proteins may play a critical role in the rendering malignant cells resistant to TGF- $\beta$ [13-15].

Thus, there are multiple etiologies of the development of drug resistance, and the role of TGF- $\beta$ regulatory system in the refractoriness of cancer cells to chemotherapeutic agents is not fully understood. In the present study, we have compared the effect of some of the most common drugs used for breast cancer treatment (doxorubicin, cisplatin and methotrexate) on the expression of mRNAs coding for TGF- $\beta$ and its receptors in the doxorubicin-sensitive and the doxorubicin-resistant human breast cancer cells. Besides, we have compared the inhibiting effect of TGF- $\beta$ on cell growth in the tested cell sub-lines in order to check if the tumor cross-refractoriness to both doxorubicin and TGF- $\beta$ may exist.
Materials and methods. Cell lines and culture conditions. Human breast carcinoma MCF-7 cells differing in their sensitivity to doxorubicin (sensitive MCF-7 (wt) and resistant (MCF-7(DOX/R) cells) were obtained from Cell Collection of the Institute of Oncology («Gliwice», Poland). The cells were cultured in the Dulbecco's modified Eagle's medium (DMEM, «Sigma Chemical Co.», USA) supplemented with $10 \%$ heat-inactivated fetal calf serum (FCS, «Sigma Chemical Co.») and $50 \mu \mathrm{g} / \mathrm{ml}$ gentamycin («Sigma Chemical Co.»). The cultured cells were maintained at $37^{\circ} \mathrm{C}$ in a humidified $(100 \%)$ incubator with $5 \% \mathrm{CO}_{2}$.

Drug treatment. Doxorubicin and cisplatin were purchased from «Ebewe» (Austria), and methotrexate from «Leberle» (USA). Each drug was added $24 \mathrm{~h}$ after cell plating and each sample was incubated for $24 \mathrm{~h}$ with the chemotherapeutic drug of appropriate concentration. Transforming growth factor $\beta_{1}$ was purchased from «R \& D Systems, Inc.» (USA).

Measuring cell number and viability. The effect of TGF- $\beta_{1}$ and doxorubicin on cell growth and viability was determined using trypan blue $(0.1 \%(\mathrm{w} / \mathrm{v}))$ exclusion method. The numbers of dead (stained) cells and alive (unstained) cells were counted in the hemocytometer chamber under the light microscope.

Isolation of total RNA and RT-PCR assay. The amount of mRNAs coding for TGF- $\beta_{1}$, TGF $\beta_{2}$, T $\beta R I$ and T $\beta R I I$ was determined by the reverse transcriptase-polymerase chain reaction (RT-PCR). Total RNA was isolated from the cells by Trizol Reagent («Life Technologies, Inc.», USA) following the standard protocol, and quantified spectrophotometrically. The first-strand cDNA synthesis and amplification of the specific DNA sequence were performed according to the manufacturer's instructions («RevertAid ${ }^{\mathrm{TM}}$ First Strand cDNA Synthesis Kit», «Fermentas», Lithuania). Briefly, $5 \mu \mathrm{g}$ of total RNA was used for cDNA synthesis using $1 \mu \mathrm{l}$ of oligo(dT) primer $(0.5 \mu \mathrm{g} / \mu \mathrm{l})$ in the presence of $1 \mu \mathrm{l}(200 \mathrm{U})$ of Moloney murine leukemia virus reverse transcriptase. The obtained cDNAs were used in RT-PCR analysis as described previously [16]. The cDNA encoding TGF- $\beta_{1}$ was amplified for 30 cycles $\left(94{ }^{\circ} \mathrm{C}\right.$ for $1 \mathrm{~min}, 65^{\circ} \mathrm{C}$ for $1 \mathrm{~min}$, and $72^{\circ} \mathrm{C}$ for $1 \mathrm{~min}$ ). The cDNA encoding TGF$\beta_{2}$ was amplified for 33 cycles $\left(94{ }^{\circ} \mathrm{C}\right.$ for $1 \mathrm{~min}, 55^{\circ} \mathrm{C}$ for $1 \mathrm{~min}$, and $72{ }^{\circ} \mathrm{C}$ for $1 \mathrm{~min}$ ). The cDNAs encoding T $\beta R I$ and T $\beta R I I$ were amplified for 30 cycles $\left(94^{\circ} \mathrm{C}\right.$ for 
The effect of TGF- $\beta_{1}(10 \mathrm{ng} / \mathrm{ml})$ and doxorubicin $(5 \mu \mathrm{g} / \mathrm{ml})$ treatment on growth and viability of $M C F-7(w t)$ and $M C F-7$ (DOX/R) cells

\begin{tabular}{|c|c|c|c|c|}
\hline Factor & \multicolumn{2}{|c|}{ MCF-7 (wt) } & \multicolumn{2}{|c|}{ MCF-7(DOX/R) } \\
\hline \multicolumn{5}{|c|}{ Time of incubation, $24 \mathrm{~h}$} \\
\hline Control & $100.0 \pm 2.4$ & $2.0 \pm 0.3$ & $100.0 \pm 3.2$ & $3.0 \pm 0.5$ \\
\hline Doxorubicin & $24.0 \pm 2.5 * *$ & $3.0 \pm 0.6$ & $95.0 \pm 2.8$ & $2.0 \pm 0.5$ \\
\hline \multicolumn{5}{|c|}{ Time of incubation, $48 \mathrm{~h}$} \\
\hline Control & $100.0 \pm 1.5$ & $4.0 \pm 0.8$ & $100.0 \pm 1.6$ & $3.0 \pm 0.9$ \\
\hline Doxorubicin & $13.0 \pm 1.5^{* *}$ & $7.0 \pm 0.9^{*}$ & $90.0 \pm 4.5^{*}$ & $5.0 \pm 0.5$ \\
\hline
\end{tabular}

${ }^{*} \mathrm{p}<0.05 ; * * \mathrm{p}<0.001$ (in treated versus the respective control (untreated) cells).

$1 \mathrm{~min}, 55^{\circ} \mathrm{C}$ for $1 \mathrm{~min}$, and $72{ }^{\circ} \mathrm{C}$ for $1 \mathrm{~min}$ ). The cDNA encoding $\beta$-actin was amplified for 25 cycles $\left(94^{\circ} \mathrm{C}\right.$ for $1 \mathrm{~min}, 65^{\circ} \mathrm{C}$ for $1 \mathrm{~min}$, and $72^{\circ} \mathrm{C}$ for $1 \mathrm{~min}$ ). The expected sizes of the PCR products and the primer sequences used were as follows:

forward primer 5'-TGAACCGGCCTTTCCTGCT TCTCATG-3' and reverse primer 5'-GCGGAAGTC AATGTACAGCTGCCGC-3', 152 bp; TGF- $\beta_{1}$;

forward primer 5'-ACAGGAACCTGGGATTTA AAATAAG-3' and reverse primer 5'-TTTCTGATCA CCACTGGTATATGTG-3', 152 bp; TGF- $\beta_{2}$;

forward primer 5'-TGAACAGAAGTTAAGGCC AAATATC-3' and reverse primer 5'-CAGGCAAAGC TGTAGAATTACATTT-3', 192 bp; TßRI;

forward primer 5'-CGGTTAATAACGACATGA TAGTCAC-3' and reverse primer 5'-TCATGGCAAA CTGTCTCTAGTGTTA-3', 217 bp; T $\beta$ RII;

forward primer 5'-TCACCCACACTGTGCCCAT CTA-3' and reverse primer 5'-CAGCGGAACCGCTC ATTGCCAA-3', 295 bp; $\beta$-actin.

$\beta$-Actin was used as an internal control for normalizing the amount of sample loading.

The reaction products were analyzed by electrophoresis in $2 \%$ agarose gels and visualized by ethidium bromide staining of DNA. Gels were examined under UVlight using the transilluminator Macro Vue UV-20 («Hoeffer Pharmacia Biotech Inc.», USA) and photographed using the Olympus C-4000 digital camera. Semiquantitation of the ethidium bromide stained DNA bands was performed using the Gel-Pro Analyzer v3.1.00.00 program («Media Cybernetics, L. P.», USA).
Statistical analysis. The experiments were repeated 3 times and significance of difference was assessed by Student's t-test. The level of significance was set at 0.05 .

Results and discussion. Our previous study has shown that the MCF-7(DOX/R) cells, comparing to the MCF-7(wt) cells, are more refractory to the cytotoxic and cytostatic effects of the studied anticancer drugs [17] and ionizing radiation [18]. We also have revealed a higher DNA repair potential in the MCF-7 (DOX/R) cells than in the MCF-7(wt) cells [19]. The treatment of the MCF-7 and T47D cell lines of human breast carcinoma with doxorubicin $(1-100 \mu \mathrm{g} / \mathrm{ml})$ induced a secretion of TGF- $\beta_{1}$ by both cell lines in a dose-dependent manner [20]. An elevated level of TGF- $\beta_{1}$ was detected in the blood plasma of breast [21], lung [22], colorectal $[23,24]$ cancer patients and metastatic patients with prostate cancer [25].

In order to compare the sensitivity of studied cells to TGF- $\beta_{1}$, the cells were incubated in the absence (control) or presence of TGF- $\beta_{1}(10 \mathrm{ng} / \mathrm{ml})$ for 24 and $48 \mathrm{~h}$. We found that the MCF-7(wt) cells were more sensitive to the growth inhibition by the exogenous TGF- $\beta_{1}$ action than the MCF-7(DOX/R) cells (Table). The TGF- $\beta_{1}$ inhibited growth and caused cell death $(16.5 \pm 2.3 \%)$ of the MCF-7(wt) cells $(\mathrm{p}<0.001)$ after a $48 \mathrm{~h}$ incubation, whereas in the similarly treated MCF-7 (DOX/R) cells no statistically significant changes were observed in the growth inhibition comparing to the control (untreated) cells of that sub-line. Doxorubicin $(5 \mu \mathrm{g} / \mathrm{ml})$ was used as a positive control of the drug effect on the cell growth and viability of the sensitive and resistant sub-lines of 


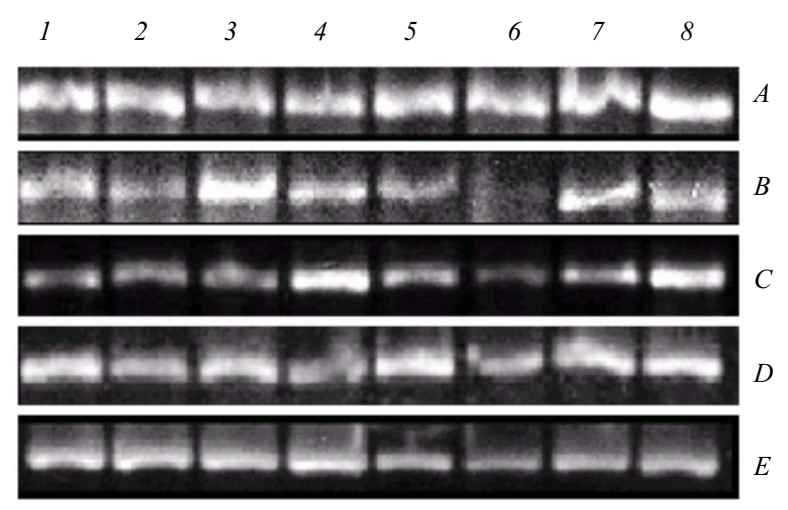

Fig. 1. Representative RT-PCR analysis of cDNA corresponding mRNA coding for TGF- $\beta_{1}(A)$, TGF- $\beta_{2}(B)$, T $\beta \mathrm{RI}(C)$, T $\beta \mathrm{RII}(D)$ and $\beta$-actin $(E)$ in MCF-7(wt) cells (1-4) and MCF-7(DOX/R) cells (5-8): 1,5 - untreated cells; 2,6 - doxorubicin $(5 \mu \mathrm{g} / \mathrm{ml}) ; 3,7$ - methotrexate $(25 \mu \mathrm{g} / \mathrm{ml}) ; 4,8-$ cisplatin $(10 \mu \mathrm{g} / \mathrm{ml})$

the MCF-7 cells (Table). It is known that during the early phase of epithelial tumorigenesis, TGF- $\beta$ inhibits the primary tumor development and growth by inducing the cell cycle arrest and apoptosis. At the late stages of tumor progression when the tumor cells become resistant to the growth inhibition by TGF- $\beta$ due to inactivation of the TGF- $\beta$ signaling pathway or aberrant regulation of the cell cycle, TGF- $\beta$ exhibits a pro-metastatic role [26]. Earlier it has been found that the cisplatin-resistant sub-line of murine leukemia L1210 cells possesses a cross-resistance to TGF- $\beta_{1}$ and the mechanism of drug resistance, based on the involvement of TGF- $\beta_{1}$, has been proposed [27].

We also studied whether the above mentioned anticancer drugs can alter the expression of mRNAs for TGF- $\beta$ and its receptors in the MCF-7(wt) and the MCF-7(DOX/R) cells. The cells of both sub-lines were exposed to different doses of the anticancer drugs, doxorubicin $(5 \mu \mathrm{g} / \mathrm{ml})$, methotrexate $(25 \mu \mathrm{g} / \mathrm{ml})$ and cisplatin $(10 \mu \mathrm{g} / \mathrm{ml})$ at $24 \mathrm{~h}$ exposure. When using $\beta$-actin as an internal control for normalizing the amount of sample loading, we found that the levels of mRNAs coding for TGF- $\beta_{1}$, TGF- $\beta_{2}$, T $\beta R$ I and T $\beta R I I$, were higher in the untreated MCF-7(DOX/R) cells comparing to the untreated MCF-7(wt) cells (Fig. 1 and Fig. 2). It was reported that the expression of mRNAs coding for TGF$\beta_{2}$ and TGF- $\beta$ receptors (T $\beta R I$ and T $\beta$ RII) was higher in most malignant tumor cells, for example, in the breast cancer cells of Hs578T line [28]. Thus, we hypothesize that the genes of the TGF- $\beta$ regulatory system, the ex- pression of which is higher in the doxorubicin-resistant cancer cell line (MCF-7(DOX/R)), may be responsible for the observed chemoresistance via their protein products.

The results presented in Fig. 1 and Fig. 2, A, show that under the doxorubicin action there was no statistically significant increase in the expression of the TGF$\beta_{1}$ mRNA in both cell lines tested, whereas a decrease in the expression of the TGF $-\beta_{2}$ mRNA was revealed in the MCF-7(wt) and MCF-7(DOX/R) cells (1.4 and 2.3 fold, correspondingly) (Fig. 2, B). Methotrexate and cisplatin did not affect the expression of mRNAs coding for TGF- $\beta_{1}$ ligand in both studied cancer cell lines (Fig. $2, A)$. We found an increase in the TGF- $\beta_{2}$ mRNA expression in the MCF-7(wt) cells treated with methotrexate and in the MCF-7(DOX/R) cells treated with methotrexate and cisplatin (Fig. 2, B).

TGF- $\beta$ s elicit their effects via binding with receptors on the cellular surface [10]. T $\beta R I$ and T $\beta R I I$ form a heteromeric receptor complex. The direct involvement of both T $\beta R I$ and T $\beta R I I$ in conferring TGF- $\beta$ s effects indicates that the loss of either of the functional receptors would contribute to the failure to respond to autocrine and exogenous TGF- $\beta[13,14,29]$. It has been shown that the mutational inactivation of T $\beta R I I$ occurs frequently in a subset of the microsatellite unstable colon cancers [30]. The inactivation of TRRII has also been described in the non-small cell lung adenocarcinomas and the small cell lung carcinomas [31]. Several studies describe the mutations in T $\beta R I$ and T $\beta R I I$ in the adenomas and gliomas [32-34] as well as a correlation between higher expression of T $\beta R I$ and T $\beta R I I$ and more aggressive glioma cell lines and tumors $[35,36]$.

The treatment of cells with doxorubicin and methotrexate decreased the production of mRNA coding for T $\beta R I$ ( 2.0 and 1.4 fold, correspondingly) in the doxorubicin-resistant sub-line, while no statistically significant changes in the level of TRRI mRNA were found in the doxorubicin-sensitive sub-line under the same conditions (Fig. 2, C). A two-fold increase of mRNA coding for TRRI was detected in the MCF-7(wt) cells treated with cisplatin. At the moment, the reasons for such dynamics in the T $\beta$ RI expression in MCF-7(wt) cells under cisplatin treatment are unknown, and additional studies are needed to get a support for such explanation of the detected differences. 

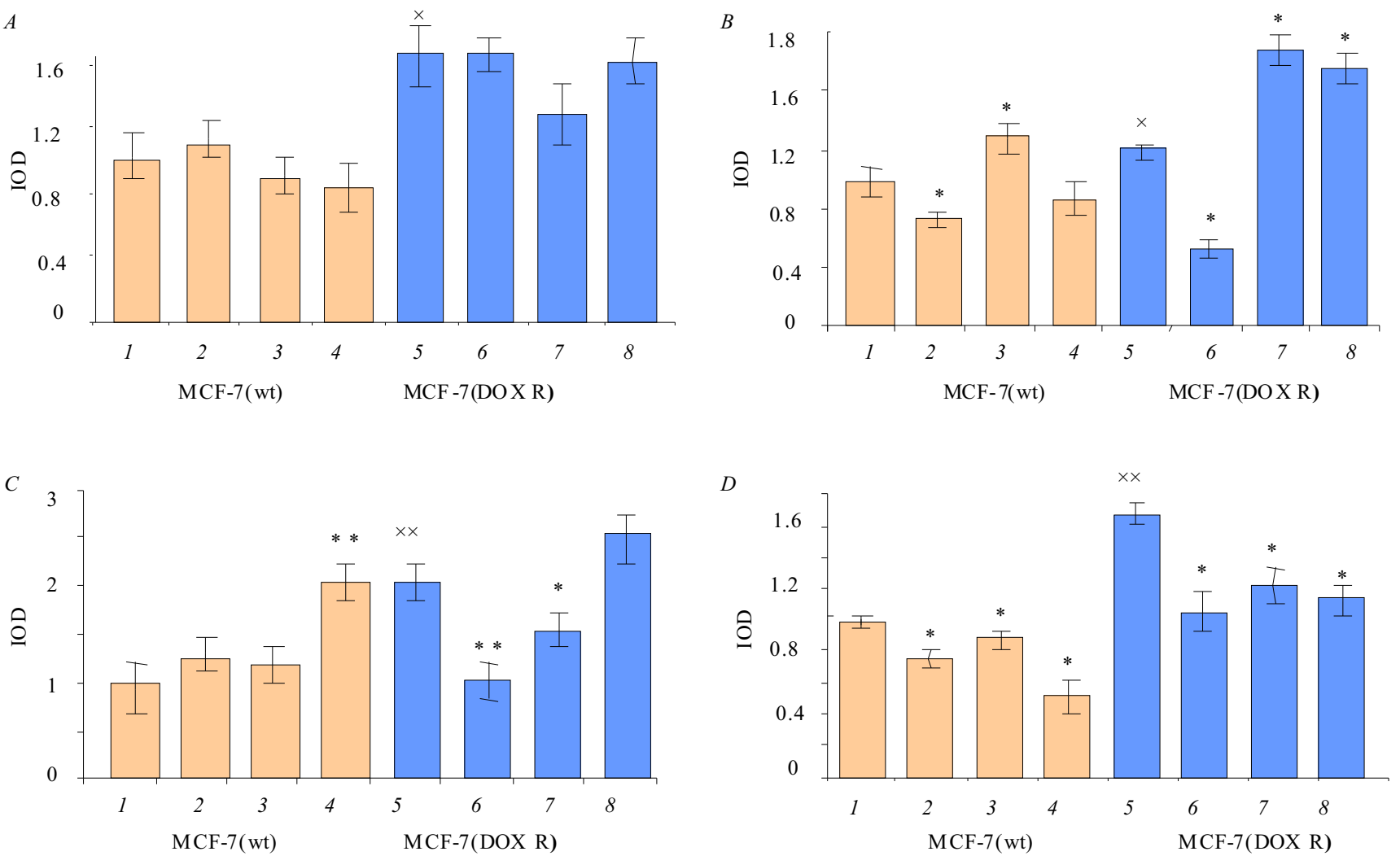

Fig. 2. Densitometric measurement of cDNA corresponding mRNA coding for TGF- $\beta_{1}(A)$, TGF- $\beta_{2}(B)$, T $\beta$ RI $(C)$ and T $\beta$ RII $(D)$ mRNAs normalized against $\beta$-actin mRNA levels in MCF-7(wt -yellow) (1-4) and MCF-7(DOX/R-blue) (5-8) cells: 1,5 - untreated cells; 2,6 - doxorubicin $(5 \mu \mathrm{g} / \mathrm{ml}) ; 3,7$ - methotrexate $(25 \mu \mathrm{g} / \mathrm{ml}) ; 4,8$ - cisplatin $(10 \mu \mathrm{g} / \mathrm{ml}) ;{ }^{\times} \mathrm{p}<0.05 ;{ }^{*} \mathrm{p}<0.01$ (in MCF-7(DOX/R) versus $\mathrm{MCF}-7(\mathrm{wt})$ cells); ${ }^{*} \mathrm{p}<0.05$; $* * \mathrm{p}<0.01$ (in cells treated by anticancer drugs versus the respective control (untreated) cells)

We also revealed a decreased expression of the mRNA coding for T $\beta$ RII in both studied cell sub-lines under the action of anticancer drugs used. The most prominent effect on the MCF-7(wt) cells was found for the cisplatin action, while in MCF-7(DOX/R) cells - for the doxorubicin action (Fig. 2,D). Earlier, it has been established that anticancer drugs doxorubicin and cisplatin decrease the expression of the mRNA coding for T $\beta$ RII in the human lung adenocarcinoma A549 cells, and cause the changes in the post-receptor Smad-dependent TGF- $\beta_{1}$ signaling pathway [37].

In summary, we have got the evidence that the resistance of the human breast cancinoma cells to doxorubicin is a multi-factorial phenomenon. The multi-factorial resistance to doxorubicin might explain the crossresistance of MCF-7(DOX/R) cells to other compounds (methotrexate and cisplatin) which are even not structurally related.

The following conclusions can be suggested taking into account the results obtained: 1) tumor cell refracto- riness of the MCF-7(DOX/R) cells to both doxorubicin and TGF- $\beta_{1}$ was found; 2 ) the studied anticancer drugs (doxorubicin, methotrexate and cisplatin) can inhibit the transduction of TGF- $\beta$ regulatory signals in both cell sub-lines tested owing to the violation of the corresponding signal pathway at different levels, particularly by decreasing the expression of the mRNA coding for T $\beta R I I ; 3)$ TGF- $\beta$ might affect the response of the breast cancer cells to the anticancer drugs, thereby, allowing for a possibility of chemotherapeutic modulation.

Вплив протипухлинних препаратів на клітини карциноми молочної залози, чутливі та стійкі до доксорубіцину: експресія мРНК ТФР- $\beta$ і його рецепторів

I. В. Чорна, О. В. Федоренко, Р. С. Стойка

Резюме

Мета. Порівняльний аналіз впливу протипухлинних препаратів (доксорубіцину, метотрексату і циисплатину) та ТФР-ß на клітини карииноми молочної залози людини лінії MCF-7, чутливі (wt) $i$ стійкі (DOX/R) до дї доксорубіцину. Методи. Напівкількісну полімеразну ланцюгову реакцію (ПЛР) використовували для визна- 
чення експресї мРНК ізоформ ТФР- $\beta$ (ТФР- $\beta_{1}$ і ТФР- $\left.\beta_{2}\right)$ та рецеп-

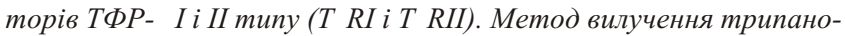
вого синього застосовано для виявлення кількості і життєздатності клітин. Результати. Клітинам лінії MCF-7(DOX/R) притаманна більша стійкість до рістінгібувальної дії ТФР- $\beta_{l}$, ніж клітинам лінї МCF-7(wt). Рівень мРНК ТФР- $\beta$ і його рецепторів виявився вищим у необроблених клітинах $M C F-7(D O X / R)$ порівняно з клітинами MCF-7(wt). Експресія мРНК TßRII знижувалася в обох клітинних лініях, оброблених доксорубіцином, метотрексатом $i$ циисплатином, тоді як падіння рівня мPHК TRRI спостерігали лише в клітинах $M C F-7(D O X / R)$, підданих впливу доксорубіцину і метотрексату. Висновки. Встановлено відмінності в дії досліджених протипухлинних препаратів і ТФР- $\beta$ на доксорубічин-чутливі $i$-стійкі клітини. Подальші дослідження необхідні для з'ясування молекулярних механізмів уникнення рістінгібувальної дї ТФР- $\beta$ клітинами лінї MCF-7(DOX/R).

Ключові слова: МCF-7, ТФР- $\beta$, доксорубіцин, метотрексат, иисплатин, резистентність.

Влияние противоопухолевых препаратов на клетки карциномы молочной железы, чувствительные и устойчивые к доксорубицину: экспрессия мРНК ТФР- $\beta$ и его рецепторов

И. В. Черная, А. В. Федоренко, Р. С. Стойка

Резюме

Цель. Сравнительный анализ влияния противоопухолевых препаратов (доксорубицина, метотрексата и ичисплатина), а также TФР- $\beta$ на клетки карииномы молочной железы человека линии MCF-7, чувствительные (wt) и устойчивые (DOX/R) к действию доксорубицина. Методы. Полуколичественную полимеразную цепную реакцию (ПЦР) использовали для определения экспрессии мРНК изоформ ТФР- $\beta\left(\right.$ ТФР- $\beta_{1}$ и ТФР- $\left.\beta_{2}\right)$ и реиепторов ТФР- $\beta$ I и II типа (TBRI и TBRII). Метод исключения трипанового синего применен для установления количества и жизнеспособности клеток. Результаты. Клеткам линии MCF-7(DOX/R) свойственна большая устойчивость к ростингибирующему действию ТФР- ${ }_{1}$, чем клеткам линии MCF-7(wt). Уровень мРНК ТФР- $\beta$ и его рецепторов оказался выше в необработанных клетках MCF-7(DOX/R) по сравнению с клетками MCF-7(wt). Экспрессия мРHК TßRII снижалась в обеих клеточных линиях, обработанных доксорубииином, метотрексатом и иисплатином, тогда как падение уровня мPHK TRRI выявлено только в клетках MCF-7(DOX/R), подвергшихся влиянию доксорубицина и метотрексата. Выводы. Установлены различия в действии изученных противоопухолевых препаратов и ТФР- $\beta$ на доксорубицин-чувствительные и -устойчивые клетки. Дальнейшие исследования необходимы для выяснения молекулярных механизмов избежания ростингибирующего действия ТФР- $\beta$ клетками линии $M C F-7(D O X / R)$.

Ключевые слова: $M C F-7$, ТФР- $\beta$, доксорубицин, метотрексат, цисплатин, резистентность.

\section{REFERENCES}

1. Aljarrah K, Mhaidat NM, Al-Akhras MA, Aldaher AN, Albiss B, Aledealat K, Alsheyab FM. Magnetic nanoparticles sensitize MCF-7 breast cancer cells to doxorubicin-induced apoptosis. World J Surg Oncol. 2012; 10:62.

2. Minotti G, Menna P, Salvatorelli E, Cairo G, Gianni L. Anthracyclines: molecular advances and pharmacologic developments in antitumor activity and cardiotoxicity. Pharmacol Rev. 2004; 56(2):185-229.
3. Florea AM, Busselberg D. Cisplatin as an anti-tumor drug: cellular mechanisms of activity, drug resistance and induced side effects. Cancers (Basel). 2011; 3(1):1351-71.

4. Skubisz MM, Tong $S$. The evolution of methotrexate as a treatment for ectopic pregnancy and gestational trophoblastic neoplasia: a review. ISRN Obstet Gynecol. 2012; 2012:637094.

5. Baguley $B C$. Multiple drug resistance mechanisms in cancer. Mol Biotechnol. 2010; 46(3):308-16.

6. Gillet JP, Gottesman MM. Mechanisms of multidrug resistance in cancer. Methods Mol Biol. 2010; 596):47-76.

7. Higgins $C F$. Multiple molecular mechanisms for multidrug resistance transporters. Nature. 2007; 446(7137):749-57.

8. Chekhun VF, Kulik GI, Yurchenko OV, Tryndyak VP, Todor IN, Luniv LS, Tregubova NA, Pryzimirska TV, Montgomery B, Rusetskaya NV, Pogribny IP. Role of DNA hypomethylation in the development of the resistance to doxorubicin in human MCF-7 breast adenocarcinoma cells. Cancer Lett. 2006; 231(1):87-93.

9. Lukyanova NY, Rusetskya NV, Tregubova NA, Chekhun VF. Molecular profile and cell cycle in MCF-7 cells resistant to cisplatin and doxorubicin. Exp Oncol. 2009; 31(2):87-91.

10. Connolly EC, Freimuth J, Akhurst RJ. Complexities of TGF- $\beta$ targeted cancer therapy. Int J Biol Sci. 2012; 8(7):964-78.

11. Papadopoulou E, Anagnostopoulos K, Tripsianis G, Tentes I, Kakolyris $S$, Galazios G, Sivridis E, Simopoulos K, Kortsaris A. Evaluation of predictive and prognostic significance of serum TGF-beta1 levels in breast cancer according to HER-2 codon 655 polymorphism. Neoplasma. 2008; 55(3):229-38.

12. Dancea HC, Shareef MM, Ahmed MM. Role of radiation-induced TGF-beta signaling in cancer therapy. Mol Cell. Pharmacol. 2009; 1(1):44-56.

13. Barcellos-Hoff MH, Akhurst RJ. Transforming growth factorbeta in breast cancer: too much, too late. Breast Cancer Res. 2009; 11(1):202.

14. Calone I, Souchelnytskyi S. Inhibition of TGF $\beta$ signaling and its implications in anticancer treatments. Exp Oncol. 2012; 34(1): 9-16.

15. Chowdhury S, Ammanamanchi S, Howell GM. Epigenetic targeting of transforming growth factor $\beta$ receptor II and implications for cancer therapy. Mol Cell Pharmacol. 2009; 1(1):57-70.

16. Chorna I, Fedorenko O, Datsyuk L, Stoika R. Expression of mRNA coding for TGF-beta and its receptors in irradiated human breast carcinoma MCF-7 cells differing in their sensitivity to doxorubicin. Exp Oncol. 2005; 27(2):156-8.

17. Filyak $O$, Stoika RS. Comparative study of p53 expression in human carcinoma cell lines A549 and MCF7 under anticancer drug treatment. Ukr Biokhim Zh. 2005; 77(2):136-40.

18. Chorna I, Bilyy R, Datsyuk L, Stoika R. Comparative study of human breast carcinoma MCF-7 cells differing in their resistance to doxorubicin: effect of ionizing radiation on apoptosis and TGF$\beta$ production. Exp Oncol. 2004; 26(2):111-7.

19. Chorna IV, Datsyuk LO, Stoika RS. Expression of Bax, Bad and Bcl-2 proteins under X-radiation effect towards human breast carcinoma MCF-7 cells and their doxorubicin-resistant derivatives. Exp Oncol. 2005; 27(3):196-201.

20. Stoika RS, Yakymovych IA, Kashchak NI, Boyko MM, Korynevska AV, Klyuchyvska OY, Shafranska GI, Yakymovych MY, Zhylchuk VY, Kudryavets YY, Vorontsova AL. Effect of anticancer drugs on production of transforming growth factor and expression of $\mathrm{p} 53$ AND Bcl-2 proteins by MCF-7 and T47D cell lines of human breast carcinoma. Exp Oncol. 2008; 30(1):35-41.

21. Sheen-Chen SM, Chen HS, Sheen CW, Eng HL, Chen WJ. Serum levels of transforming growth factor betal in patients with breast cancer. Arch Surg. 2001; 136(8):937-40. 
22. Gonzalez-Santiago AE, Mendoza-Topete LA, Sanchez-Llamas F, Troyo-Sanroman R, Gurrola-Diaz CM. TGF- $\beta 1$ serum concentration as a complementary diagnostic biomarker of lung cancer: establishment of a cut-point value. J Clin Lab Anal. 2011; 25 (4):238-43.

23. Kemik O, Kemik AS, Purisa S, Hasirci I, Dulger AC, Adas M, Tuzun $S$. Transforming growth factor beta-1 in human colorectal cancer patients. Eur J Gen Med. 2011; 8(1):53-6.

24. Shim KS, Kim KH, Han WS, Park EB. Elevated serum levels of transforming growth factor- $\beta 1$ in patients with colorectal carcinoma: its association with tumor progression and its significant decrease after curative surgical resection. Cancer. 1999; 85(3): 554-61.

25. Adler HL, McCurdy MA, Kattan MW, Timme TL, Scardino PT, Thompson TC. Elevated levels of circulating interleukin-6 and transforming growth factor-beta1 in patients with metastatic prostatic carcinoma. J Urol. 1999; 161(1):182-7.

26. Jaowlew $S B$. Transforming growth factor-beta in cancer and metastasis. Cancer Metastasis Rev. 2006; 25(3):435-57.

27. Stoika R, Yakymovych M, Souchelnytskyi S, Yakymovych I. Potential role of transforming growth factor beta1 in drug resistance of tumor cells. Acta Biochim Pol. 2003; 50(2):497-508.

28. Gomes LR, Terra LF, Wailemann RA, Labriola L, Sogayar MC. TGF- $\beta 1$ modulates the homeostasis between MMPs and MMP inhibitors through p38 MAPK and ERK1/2 in highly invasive breast cancer cells. BMC Cancer. 2012; 12:26.

29. Nagaraj NS, Datta PK. Targeting the transforming growth factor-beta signaling pathway in human cancer. Expert Opin Investig Drugs. 2010; 19(1):77-91.

30. Biswas S, Trobridge P, Romero-Gallo J, Billheimer D, Myeroff LL, Willson JK, Markowitz SD, Grady WM. Mutational inactivation of TGFBR2 in microsatellite unstable colon cancer arises from the cooperation of genomic instability and the clonal outgrowth of transforming growth factor beta resistant cells. Genes Chromosomes Cancer. 2008; 47(2):95-106.

31. Kim SJ, Im YH, Markowitz SD, Bang YJ. Molecular mechanisms of inactivation of TGF-beta receptors during carcinogenesis. Cytokine Growth Factor Rev. 2000; 11(1-2):159-68.

32. Fujiwara K, Ikeda H, Yoshimoto T. Abnormalities in expression of genes, mRNA, and proteins of transforming growth factorbeta receptor type I and type II in humanpituitary adenomas. Clin Neuropathol. 1998; 17(1):19-26.

33. Izumoto S, Arita N, Ohnishi T, Hiraga S, Taki T, Tomita N, Ohue $M$, Hayakawa $T$. Microsatellite instability and mutated type II transforming growth factor-beta receptor gene in gliomas. Cancer Lett. 1997; 112(2):251-6.

34. Kubiczkova L, Sedlarikova L, Hajek R, Sevcikova S. TGF- $\beta$ - an excellent servant but a bad master. J Transl Med. 2012; 10:183.

35. Kellman C, Olofsson SP, Hansson O, Von Schantz T, Lindvall $M$, Nilsson I, Salford LG, Sjogren HO, Widegren B. Expression of TGF- $\beta$ isoforms, TGF- $\beta$ receptors, and Smad molecules at different stages of human glioma. Int J Cancer. 2000; 89(3):251-8.

36. Yamada N, Kato M, Yamashita H, Nister M, Miyazono K, Heldin $\mathrm{CH}$, Funa $\mathrm{K}$. Enhanced expression of transforming growth factor- $\beta$ and its type-I and type-II receptors in human glioblastoma. Int J Cancer. 1995; 62(4):386-92.

37. Filyak $Y$, Filyak $O$, Stoika $R$. Transforming growth factor beta-1 enhances cytotoxic effect of doxorubicin in human lung adenocarcinoma cells of A549 line. Cell Biol Int. 2007; 31(8):851-5.

Received 14.05.13 